\title{
Financial Impact of Digital Technologies as a Promising Element of Import Substitution
}

\author{
Elvira Ildarovna Bulatova ${ }^{1} \&$ Elmira Faylovna Amirova ${ }^{2}$ \\ ${ }^{1}$ Department of Economics, Kazan Federal University, Kazan, Russia \\ ${ }^{2}$ Department of Economics, Kazan State Agrarian University, Kazan, Russia \\ Correspondence: Elvira Ildarovna Bulatova, PhD, Associate Professor, Department of Economics, Kazan Federal \\ University, Kazan, Russia. Tel: 7-917-390-0555.
}

Received: August 5, 2020

doi:10.5430/ijfr.v11n5p392
Accepted: September 19, 2020

Online Published: October 4, 2020

URL: https://doi.org/10.5430/ijfr.v11n5p392

\begin{abstract}
This article examines the financial elements of agricultural production digital architecture in Russia during the transition to the fourth technological stage in order to compete and import substitution in the agro-industrial market of the country. The pandemic and its consequences have had a negative impact on the Russian economy, in the context of the country's insufficient food security and the inevitable increase in prices for imported goods, due to rising prices for hydrocarbons and the predominance of low-value-added food products in exports. Due to the weakening of the ruble against the falling oil prices, the economy may face the need for a new wave of import substitution. This study identifies the problems of the agricultural sector and the reasons for Russia's high dependence on imports justify the need to develop high-tech technologies. Authors determined the development directions of agricultural production digitalization in Russia through innovative agricultural technologies based on the Internet of things, distributed computing, and artificial intelligence technologies. Increasing the level of the agro-industrial complex development, bringing it to a new independent stage, is vital. However, it is impossible without state support and the digitalization of technological processes.
\end{abstract}

Keywords: modernization, digital economy, digitalization, agriculture, automation, import substitution of products

\section{Introduction}

In the current pandemic era, numerous changes occur in the form of an increasing geopolitical struggle on world markets. The most optimal solution to the agricultural sector issue is the transition to digital agriculture (precision farming, active use of digital technologies to increase labor productivity).

In recent years, issues of ensuring food security in Russia have become very topical. The high domestic food market dependence on imported food and agricultural raw materials poses a threat to Russia's food security. The main reasons for the high dependence on imports include insufficient development of the raw material base (production sector) due to the small-scale level, which does not correspond to the rate of accelerated increase in production volumes. Another notable reason is low rates of modernization and renewal of necessary production assets (this applies to the production sector, and underdevelopment in the sphere of processing, although this is an area where the use of innovations will highly likely influence the profitability of production) (Iskhakov, 2019). Furthermore, financial instability, the unsatisfactory level of market infrastructure, lack of qualified personnel (due to the very low attractiveness of labor), low rate of natural ecological reproduction potential, limited information support for the agro-industrial complex are other contributing factors. As a result, the share of imports in the market of agricultural raw materials for certain a type of products (milk, beef) is up to $18.8 \%$. The most critical factor determining the higher competitiveness of foreign food products is a higher level of state support. The need to ensure the physical and economic availability of food determines the formation of a new concept for the development of domestic agricultural production (Kirillova, 2016).

The introduction of a food embargo as a response to anti-Russian sanctions has demonstrated positive results. The Russian agricultural sector, due to a high degree of protectionism and increased budget funding, has become a driver of the Russian economy. High rates of growth in agricultural and food production ensured the enrichment of the domestic market, reducing imports while increasing exports by modern tools such as artificial intelligence (Ahmadi 
\& Movahed, 2019).

\section{Methods}

The authors used general scientific research methods in the framework of abstract-logical, comparative, and dialectical analysis. The study also used statistical and economic analysis, reflecting the development issues of the agricultural sector and scientific and technical achievements in the development of intelligent agricultural machinery, biotechnology, genetic engineering and other priority areas.

\section{Results and Discussion}

Russia is taking measures to substitute imported agricultural products. Based on the latest official data, the agro-industrial complex of Russia takes the last place in terms of digital development, which characterizes it as a sphere of the national economy that requires special attention (Sokolova et al., 2019). In recent years, the introduction of the latest nano- and biotechnologies, modernized equipment and improved types of agricultural products through genomics has been expanding in the agricultural sector. Special state programs of support and development were also implemented for domestic agricultural producers. Digital technologies play a leading role in the process of food import substitution. According to the Ministry of agriculture of Russia data, Russia ranks 15th in the world in terms of digitalization - meanwhile, only $10 \%$ of all work on arable land is performed using advanced technologies. If we compare the level of state support for agriculture across the world, the state support for the Russian agro-industrial complex is 32 billion USD. This insufficient thus causes slow development of the country's agricultural sector (Table 1).

Table 1. Level of state support for agriculture by country

\begin{tabular}{llllll}
\hline \multirow{2}{*}{ Indicators } & Countries & & & \\
\cline { 2 - 6 } & Russia & USA & EU & China & Japan \\
\hline Arable land area, million ha & 124 & 165 & 121 & 124 & 5 \\
\hline Level of state support, bln USD & 4 & 24 & 108 & 147 & 64 \\
\hline Subsidies per 1 ha & 32 & 145 & 893 & 1185 & 12800 \\
\hline
\end{tabular}

One of the main issues of agricultural business is that not every enterprise but only sufficiently capitalized ones can use advanced technologies. Ordinary farms have little access to the latest inventions due to their low investment security. However, the use of digitalization tools is forecasted to become widespread over time (Krasnoselskaya et al., 2019).

Russia is taking measures to substitute imported agricultural products. State support programs are developed for Russian agricultural producers, preferential lending is provided on favorable terms, and a food embargo is also introduced. New state programs are developing for the industry in order to provide competitive advantages (Zharova et al., 2019). They define priority areas for agricultural development and reduce food import rates. The programs include a list of activities aimed at developing the production and sale of agricultural products. Special attention is paid to investment components. Funds are allocated to the agricultural sector in the form of subsidies or grants.

Also, in the process of import substitution, it is necessary to introduce the latest digital technologies. The government starts involving farmers and small businesses in production digitization (Bunkovsky, 2019 \& Zhakhov et al. 2020). Prices for modernized equipment and machines that significantly simplify the technology of processing and growing food are reduced, and the overall time to get the final result is also reduced. One can also get the desired result for each specific customer individually (Amirova et al., 2018).

In the Russian agro-industrial complex, the formation of digital agriculture is about mastering the future. The strategic guidelines of the digital economy are reflected in geopolitics, industry development, and agribusiness management. The use of digital economy elements is possible at all stages of the "field to counter" system.

Researching this issue, we may say that the digital models of production processes creation in agriculture will improve the efficiency of agricultural producers' business. Nevertheless, this necessitates universal open agricultural management systems with hundreds of input conditions (parameters) and big data analysis with AI elements. This system includes the formation and algorithmizing of management scenarios (equipment, devices, processes, finance) for the primary processes - preparation, production, and sales ( Iskhakov, 2019, Kirillova, 2016 \& Safiullin et al., 
2019).

Each management solution platform is based on an open platform for managing the processes of crop production, animal husbandry, supply, and sales logistics, including traceability systems, a platform for seed and genetic funds, fertilization and chemistry management. The primary platform to create is the knowledge platform, which demonstrates professional involvement in creating the necessary programs and providing farms with new IT-opportunities to increase added value (Amirova \& Zakharova, 2015).

The transition from the agro-industrial complex management "in the fire brigade mode" to management based on risk planning and forecasting is also vital. In order to proceed efficiently, digital transformation requires interfaces between logistics and transport systems, also the feedback data processing systems: "counter to the manufacturer," to account for consumer needs.

This factor leads to an increasing role of non-profit associations in the scenario of the digital transformation of a specific activity field, in the system of making and implementing innovative solutions risks in the formation of integration entities, which leads to the need of creation a private-state digital ecosystem of agricultural management in the Russian Federation (Amirova, 2018).

The created platform solutions for digital agriculture are aimed at creating a modular platform for global supply and demand forecasting using satellite, tax, customs, climate, soil, statistical and other information, which is presented in established formats online.

Determining the minimum purchase price based on macro data of production and consumption, including the integration of objective data of agricultural producers, will allow taking optimal management decisions in the regulation of supply and demand. This also contributes to the personal decisions of the agricultural producer implementation for the selection of crops, state support, assistance in banking, and insurance (Amirova et al., 2019).

Thus, the automated information system (AIS) "Agricultural Subsidies", the purpose of which is to combine the key functions of the process of the agricultural sector subsidizing, is built on the software platforms: "1C: Enterprise 8". Automated information system "Agricultural Subsidies" - is the information support for the process of accounting, monitoring, and control of subsidies to support the agro-industrial complex. It also involves the analysis of subsidies by recipients and information about the financial and economic status of recipients. The system made it possible to speed up the subsidies process to agricultural producers by about 2-3 times due to a significant speedup for signing agreements between the Ministry of Agriculture of Russia and the regions of the Russian Federation (Kuchukova et al., 2016 \& Shaidullin et al., 2019).

Moreover, the Federal state information system for self-driving vehicles and trailers is designed to aggregate data on all vehicles registered by the State Technical Supervision authorities of the Russian Federation, as well as on persons admitted to driving self-driving vehicles. These AIS performs the following functions:

- Data on the accounting and supervision of the technical condition of vehicles, trailers and other types of special equipment and their condition from the state technical supervision bodies of the Russian Federation;

- Up-to-date monitoring of the equipment availability and its condition;

- Operational coordination and data by inquiries of Federal agencies (Ministry of internal Affairs of Russia, Ministry of Trade of Russia, FTS Russia) concerning information on registered vehicles, their technical condition, and the owners.

The essential automated information system is the AIS NSI, which is designed to automate the administrative processes of performing state functions and providing state services provided by the Ministry of Agriculture of the Russian Federation in electronic mode, in terms of maintaining registers, registers and NSI.

It provides the following functions:

- Maintaining reference lists for creating, editing, storing, and searching records;

- Accepting and considering applications for services rendered by the Ministry of Agriculture of the Russian Federation in electronic form;

- Integrating registers with information systems and databases of the Ministry of Agriculture of the Russian Federation;

- Increasing the speed of access to information necessary for ensuring the performance of employees;

- Eliminating risks of losing documents by storing data in electronic format in databases that have a backup, 
regularly updated copies.

The following tasks can be resolved through the digital transformation of agriculture:

- Increasing labor productivity;

- Information resources of the Ministry of Agriculture of the Russian Federation and regions integration to ensure global planning in the industry and provide accurate recommendations to market participants, including using artificial intelligence;

- Provision of public services and portals for agricultural producers in order to form mechanisms and support measures for the introduction of digital technologies in the regional (local) agro-industrial complex;

- Integration of the digital agriculture platform functionality to ensure access of agribusiness enterprises to state, banking and insurance products and development of a reverse interaction scheme (access of the listed structures to commodity-producing enterprises with their offers;

- Creating conditions (environment) for increasing the transparency of agricultural markets for farms and consumers based on the traceability of both agricultural raw materials and final products (goods) (tags, chips, identifiers, technologies, devices, systems);

- Stimulating domestic development and providing access to various digital open platforms (digital field, herd, equipment management, greenhouses, etc.) for agricultural producers and developers;

- Providing a package of personal data (matrix) and new IT capabilities of technological solutions for market participants;

- Introduction of online trading platforms and systems for promoting agricultural products (raw materials, semi-finished products, processed products), considering the size of the enterprise;

- Creation of a platform for adjusting legal acts and regulatory and technical requirements for the transition to the digital economy;

- Educational and methodological platforms (standards, methods, training programs);

- Increasing the export potential of Russian agricultural products, ensuring compatibility of production processes and standards with global ones.

Digitalization can provide significant economic, social and environmental benefits. The examples below explain how the use of digital technologies can contribute to the functioning and efficiency of agri-food systems:

- The use of mobile applications that allow farmers getting information on prices, reduces cases of market imbalance and helps farmers in planning production processes. For example, in Kenya, farmers using the M-Farm app have changed their crop mix and, as some of them reported, have changed the selling efficiency at higher prices (Baumüller, 2015). EMA-i is an early warning app developed by FAO that allows local veterinarians broadcasting information about animal diseases in real time. The application is integrated into the Global animal disease information system (EMPRES i), which provides reliable data storage by countries. EMA-i is well compatible with national animal disease reporting systems. The app supports national-level surveillance and real-time information transmission, and contributes to improving the efficiency of the early warning and response system for animal diseases, which has a significant positive impact on food security;

- Technology can support farmers in responding to disease and pest outbreaks, crop failures, and climate change in a timely manner: farmers can receive messages that prompt them to take action in advance, considering the weather forecast. MyCrop is a technology-based initiative aimed at empowering farmers by providing them with information, expertise, and resources to increase productivity and profitability and, consequently, improve living standards. It is a platform for small-scale farmers to work together based on the latest technologies (big data, machine learning, smartphones/tablets, etc.), innovative business models (agricultural platform as a service) and targeted human efforts (agricultural forecasts, products and services). MyCrop helps farmers make optimal decisions and implement them: in almost real-time, the platform allows mapping land, planning crop selection, creating work plans for individual farms, and automating work considering weather conditions, soil quality, and data on diseases, pests, and crops. MyCrop is a sustainable, data-based, scalable, intelligent, self-learning platform for real-time collaboration, providing a tool for farm management and planning, providing proactive analysis and monitoring, justifying decisions, and serving as a platform for e-Commerce (buying and selling resources and finished products);

- An example of the Internet of things (IOT) technology use in agriculture is precision farming (PF). The use of agricultural machinery management systems for sowing and fertilizing allows one to reduce the cost of seed material, 
fertilizers and fuel for the tractor, and reducing the time spent on fieldwork. Variable rationing technology and the use of unmanned aerial vehicles (UAVs) help in reducing water and pesticides consumption, reducing labor and resource costs;

- The software takes an essential place in agriculture for enterprise resource planning: it allows one to optimize any process from procurement to production and sales. The use of such software provides an opportunity for an economy (or a related enterprise) to respond to the issues related to environmental protection organically, adjust the system accordingly, and increase the return on investment in the business;

- Blockchain technologies may also be in the use. In particular, blockchain technology has been successfully applied to identify low-quality food products in food supply chains, which allowed taking timely and effective measures. The same technology allows providing consumers with information on the origin of food products, which provides its users with a competitive advantage. At the end of a two-year pilot project, the retail chain has implemented a blockchain-based technology that allows tracking every bunch of spinach and every head of lettuce. The retail giant is beginning to require suppliers of lettuce and spinach to enter data into a blockchain-based database that allows them to immediately identify sources of product contamination.

More than a hundred farms that supply Walmart with leafy vegetables will have to enter information about food supplies into a blockchain-based database that IBM has developed for Walmart and a number of other retail chains that are taking similar steps.

This initiative is fully in line with two of Walmart's strategies: a course on digitalization and an emphasis on the freshness of products offered to customers. Besides, the blockchain will help Walmart to save money. When an issue occurs again - for example, the infection of Roman lettuce with E.coli bacteria - the seller will be able to identify specific batches of the product that have become a source of risk, without removing the rest of the product from sale;

- In recent years, technologies based on the use of artificial intelligence (AI) have helped to improve the management efficiency of many agribusiness enterprises. Companies that own AI technologies help farmers assess the condition of the field and monitor each stage of the production cycle. AI technologies are transforming the agricultural sector: farmers no longer need to be physically present to evaluate their farms but can rely on data from satellites and UAVs. AI technologies can optimize the use of resources, justify timely decisions based on predictive modeling, and ensure the round-the-clock operation of monitoring systems.

The ET Agricultural Brain system developed by Alibaba allows one to determine the health status of each animal on a pig farm based on its appearance, temperature and voice recognition. In addition, by tracking how the sow sleeps, stands, what it eats, artificial intelligence will tell whether it is pregnant. The system has already been implemented by the leading pig breeding complexes in China. AI allows identifying sick hogs and minimizes the number of undesirable incidents. For example, voice recognition helps protect piglets from adults. Many sensors are installed on the farm, collecting information that creates ideal conditions for the growth of livestock; at the same time, the risk of human error is significantly reduced.

According to the developer's calculations, the use of AI technologies in pig farming will allow farmers to reduce labor costs by $30 \%-50 \%$, and reduce the fattening period by five to eight days by optimizing growth conditions. The introduction of the system in all pig farms in China would allow the country to save 50 billion yuan ( 7.5 billion USD).

- Agricultural robots (" agrobots") may have an exceptionally strong impact on agriculture in the near future. Even today, field agribots help farmers in measuring water consumption and optimizing irrigation. Fleets of small light robots can replace heavy tractors, which will gradually reduce soil compaction, restore their ability to saturate with air and improve their efficiency.

A group of specialists from Naïo Technologies has developed an agricultural robot that facilitates the work of farmers and increases the profitability of farms. DINO is a new, effective solution that allows farmers to comply with increasingly stringent standards for phytosanitary products, deal with issues related to the use of pesticides, and cope with labor shortages in the agricultural sector. The DINO weeding machine is able to purposefully fight weeds, which saves labor for the farmer throughout the season. DINO is particularly effective in controlling weeds in large fields where lettuce, carrots, onions and other vegetables are grown in rows.

\section{Summary}

Digitalization of the agro-industrial complex means the introduction of new inventions to simplify production technology and improve the result. At the moment, the agro-industrial complex of Russia is moving forward, 
showing positive dynamics in the world market of agricultural products. It is important to increase the level of development of the country's agro-industrial complex, bringing it to a new independent stage. This is impossible without state support and digitalization of technological processes. We hope that very soon Russian agronomists and farmers will be able to freely use advanced technologies, thereby reducing the volume of food imports from foreign countries.

Further development of the agricultural sector is connected not only with increasing domestic production and ensuring their own needs, but also with ensuring competitive advantages when exporting Russian products to world markets. In the context of the development of global value chains and the formation of a unified international food system, increasing the export food potential becomes crucial for ensuring the effective functioning of the entire agricultural sector of the country (Amirova et al., 2018). High indicators of self-sufficiency in food and stable growth rates of its production create favorable conditions for entering world markets and diversifying foreign supplies.

\section{Conclusions}

The expansion of the agricultural sector in the context of import substitution is related to the production digitalization and raising the competition level. Therefore, it is vital to generate products with high added value so as to offer it to the world market. Export orientation with a high level of self-sufficiency in food is the primary condition for the effectiveness of the import substitution strategy.

To elevate the level of agricultural production, specific approaches have been taken in Russia. For instance, the state participates in the distribution and redistribution of income in the agricultural sector, increased financing and lending to agriculture. In fact, agriculture is subject to mandatory state insurance against natural disasters and other events. Grants and allowances are issued for novice farmers. The agricultural complex is being developed mostly at the expense of credit funds. Thus, the state plans to attract investors in the agro-industrial complex, which is, however, currently not enough. Overall, High development rate in agricultural can guarantee the prosperity the domestic market, reducing imports yet increasing exports

\section{Acknowledgments}

The work is performed according to the Russian Government Program of Competitive Growth of Kazan Federal University.

\section{References}

Ahmadi, R., \& Movahed, S. A. H. S. (2019). Study of artificial neural networks in information security risk assessment. Journal of Management and Accounting Studies, 7(02), 1-10.

Amirova, E. F. (2018). Functioning of the grain product subcomplex in the conditions of the food embargo. Bulletin of the Kazan State Agrarian University, 13(1), 147-151.

Amirova, E. F., \& Zakharova, G. P. (2015). Methodological foundations of the organizational and economic mechanism of grain-producing systems. Bulletin of the Kazan State Agrarian University, 10(3), 9-11.

Amirova, E. F., Voronkova, O. Y., Pyurveeva, K. A., Shatalov, M. A., Panteleeva, T. A., \& Sorokina, O. A. (2018). Functioning of agroindustrial complex in the conditions of digital economy. International Journal of Mechanical Engineering and Technology, 9(12), 586-594.

Amirova, E. F., Voronkova, O. Y., Zakirova, N. R., Stepanenko, O. G., Doguchaeva, S. M., \& Murzagalina, G. M. (2019). Internet of things as a tool for development of Russia's digital economy. International Journal of Mechanical Engineering and Technology, 10(2), 1011-1019.

Bunkovsky, D. V. (2019). Entrepreneurial risk management tools. Manag, 1(37), 65-76.

Iskhakov, A. T. (2019). The development of cheese making to increase the economic activity of dairy enterprises of the Republic of Tatarstan. Proc. of the Int. Sci.-Pract, Conf. Dedicated to the 100th Anniversary of Agricult (pp. 690-694). Science, Education and Enlightenment in the Middle Volga Region: Agriculture and Food Security: Technology, Innovation, Markets, Personnel.

Kirillova, O. V. (2016). On the features of foreign trade in agricultural products of the Russian Federation, WTO coll (pp. 398-402). Sustainable Development of Agriculture in the Context of Global Risks Proc. of the Sci. and Pract. Conf.

Krasnoselskaya, D. K., Khamzina, D. R., Goloviznin, S. M., Nogovitsina, O. V., Sarapulova, A. V., \& Arishina, E. S. (2019). Determination of capital accumulation in region using benchmarking tool. Revista Espacios, 40(35). 
Kuchukova, N., Turarbekov, M., \& Agumbayeva, A. (2016). Influence of fiscal and monetary policy of Kazakhstan on modernization and economic growth in the conditions of globalization. Journal of Advanced Research in Law and Economics, 7(5), 1086-1095.

Safiullin, I. N., Ibragimov, L. G., Amirova, E. F., \& Karpova, N. V. (2019). State regulation of the agricultural sector in the context of sanctions and the development of the digital economy, Bull of Kazan State Agrar. Univer, 14(3), $133-137$

Shaidullin, R., Bulatova, E., Kurmanova, L., Khabibullin, R., \& Zhuzhoma, J. (2019). Evaluation of financial stability of Russian companies. In E3S Web of Conferences (Vol. 110, p. 02044). EDP Sciences.

Sokolova, I., Leskina, O., Orlovtseva, O., Gubanova, E., \& Kanikhin, T. (2020). Application of artificial intelligence capabilities for practical needs of participants in economic processes. Proc. of the 33th Int. Busin, Inform, Manag, Associat, Conf., IBIMA 2019 (pp. 8592-8602). Education Excellence and Innovation Management through Vision.

Zhakhov, N. V., Krivoshlykov, V. S., \& Slavova, N. A. (2020). State Influence on the Development of Digital Economy of Rational Nature Use in Agricultural Sector of the Region's Economy. Proc. of XVIII Int. Sci. and Pract (pp. 182-189). Conf. Modern Trends in Agricultural Production in the World Economy.

Zharova, M., Shirokova, S., \& Rostova, O. (2019). Management of pilot IT projects in the preparation of energy resources. In E3S Web of Conferences (Vol. 110, p. 02033). EDP Sciences.

\section{Copyrights}

Copyright for this article is retained by the author(s), with first publication rights granted to the journal.

This is an open-access article distributed under the terms and conditions of the Creative Commons Attribution license (http://creativecommons.org/licenses/by/4.0/). 